\title{
Prominence Augmentation via Nasalization in Brazilian Portuguese*
}

\author{
Andrew Nevins \\ University College London \\ a.nevins@ucl.ac.uk \\ Paula Pinheiro Costa \\ Universidade Federal do Rio de Janeiro \\ paula.trianon@outlook.com
}

Received: June 3, 2019

Accepted: August 13, 2019

\begin{abstract}
This article aims to demonstrate that dialectal and idiolectal variants of Brazilian Portuguese that exhibit rhotic metathesis (e.g. vidro > vrido 'glass'), spontaneous nasalization of high vowels (as in diachronic hibernum > inverno 'winter' and non-standard ingreja 'church'), and pretonic vowel lowering of mid-vowels are all instantiations of the same process: prominence-boosting in stressed, secondary-stressed, or word-initial positions.
\end{abstract}

Keywords: spontaneous nasalization; Brazilian Portuguese; rhotic metathesis; prominence augmentation; initial syllables

Resum. Augment de la prominència per nasalització en el portuguès del Brasil

Aquest article vol demostrar que els següents tres fenòmens que exhibeixen les varietats dialectals i idiolectals del portuguès del Brasil, i.e. la metàtesi ròtica (e.g. vidro $>$ vrido 'vidre'), la nasalització espontània de les vocals altes (com el canvi diacrònic hibernum > inverno 'hivern' o la forma no estàndard ingreja 'església') i l'abaixament de les vocals medials pretòniques, són manifestacions del mateix procés: reforçament de la prominència de les posicions tòniques, d'accent secundari o de síl·labes inicials.

Paraules clau: nasalització espontània; portuguès del Brasil; metàtesi ròtica; augment de la prominència; síl·labes inicials

* We thank Livia Camargo Souza, Gean Damulakis, Guilherme Garcia, Clàudia Pons-Moll, Arthur Santana, Filomena Sandalo, Leo Wetzels, and the editors and reviewers for valuable comments and suggestions on the analysis. 


\section{Table of Contents}
1. Overview
4. Nasality as a Contributor of Weight
2. Prominence-Demanding Positions in Brazilian Portuguese
3. Spontaneous Nasalization as Prominence-Augmentation
5. Conclusions and future directions References
Appendix: List of Non-Standard forms with Spontaneous Nasalization

\section{Overview}

Nasality on vowels is a well-known feature of Portuguese, a diachronic development from nasal coda consonants, with the existence of forms such as Spanish lana,

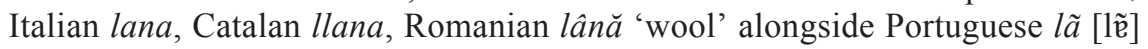
clearly demonstrating the latter language lost the coda consonant altogether, in favor of nasalization of the preceding vowel. There are, however, what are called 'non-etymological' cases of nasalization found in Portuguese (alongside the well-known case of muito [mũj.to] 'many', standardly nasalized and simply not orthographically indicated), and these are the non-standard (and sometimes

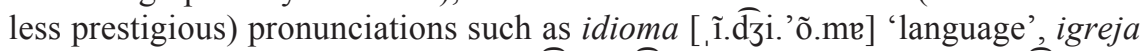

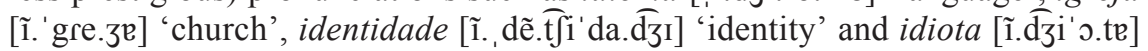
'idiot' with a initial nasal vowel, the last of which is even rendered, tongue-incheek, in the official promotional poster for the movie Bob Esponja: O Incrível Resgate). ${ }^{1}$ All of these preceding forms - some of the most representative and wellknown cases - have in common the fact that they involve a high front vowel in the initial syllable, and through a quantitative analysis of over two hundred examples presented within this paper, we conclude that there is a pattern informing why spontaneous nasalization arises in examples such as these, as opposed to being randomly articulatorily distributed throughout the language. In short, we claim that spontaneous nasalization is a strategy to perceptually enhance prominence, and tends towards particular vowels in particular syllabic positions, arising indeed potentially 'spontaneously', as opposed to being a case of variable dialectal lexicalization.

Thus, during a visit to a virtually unknown fishing village in Brazil named Picinguaba [pi.sĩ.' gwa.be], a highly literate Portuguese speaker called it [pĩ.si.' 'gwa. be], apparently transposing the nasal vowel to the first syllable. This 'real-time error' was not the result of dialectal divergence (as the toponym is so low frequency that one cannot claim there are two lexicalized variants), but rather, we contend, revealing of a latent and recurring tendency that occurs in the language: to make stressed syllables even more prominent than they otherwise would be. Specifically, the foot structure of this four-syllable word is composed of two trochees, whereby the initial syllable has secondary stress (see Collischonn 1994). The strong syllable within the first foot should ideally have more prominence than the weaker syllable in this foot. Transposing the nasality from the prosodically weaker syllable onto the stronger one

1. See $<$ https://cosmonerd.com.br/filmes/noticias/bob-esponja-o-incrivel-resgate-ganha-cartaznacional-bem-humorado/>. 
accomplishes just that, in a manner similar to what Smith (2005) called Prominence Augmentation.

The intuition is that certain prominent positions, in particular, stressed and/ or initial syllables, demand the presence of prominence-increasing material (a clearly violable tendency, but one present, the force of which when exerted can be observed). Highlighting this particular case with a version of Zoll's (1998) CoINCIDE constraints, which demand marked segments such as nasal vowels in initial syllables, would look as follows: ${ }^{2}$

(1) Tableau for Nasal Metathesis towards Initial Syllable

\begin{tabular}{|l|c|c|c|}
\hline / pi.sĩ.' gwa.be/ & COINCIDE $\left(\sigma_{1}\right.$ NasalV) & DeP [+nasal] & LINEARITY \\
\hline [pĩ.si. 'gwa.be] & & & $*$ \\
\hline [ pi.sĩ.' gwa.be] & $* !$ & & \\
\hline [ pĩ.sĩ.' gwa.be] & & $* !$ & \\
\hline
\end{tabular}

With this small 'error' in encoding and reproducing the town's toponym, we have an entire phonological tendency writ small: what properties of this particular word are responsible? This requires spelling out the following three questions for Brazilian Portuguese: (A) when does a syllable require prominence (i.e. a theory of secondary stress and prominent positions), as in the case of the initial syllable of this four-syllable paroxytone word? (B) what kinds of syllables are needier than others (e.g. those with higher vowels, or those with one or fewer consonants in the onset)? (C) What kinds of processes (and segments) can be employed to enact prominence-boosting, and how can these be formally represented?

The Stress-to-Weight Principle (SWP; e.g. Prince 1990) is employed to explain cases in which a stressed syllable (whether lexically or predictably stressed) undergoes additional phonological processes to gain weight, such as addition of a coda consonant (in Italian raddoppiamento sintattico; Borrelli 2002) or post-tonic syncope in Tonkawa (Gouskova 2007), and this principle affords insight into a wide range of strategies. Indeed, glide insertion before [s] in final-stressed syllables in the Carioca dialect (Rio de Janeiro) of Brazilian Portuguese (BP) (e.g. rapa[j]s 'guy') has been analyzed in Nevins (2015) as an instance of the SWP, under the assumption that coda [s] is non-moraic and hence such stressed syllables require additional weight. Nonetheless, there are certain processes affecting primary (and secondary) stressed syllables that cannot be easily modeled in terms of weightaddition via moraic structure per se, but nonetheless do involve a broader notion of prominence (see e.g. Ryan 2014 for application of this notion for weight-to-stress cases), as shown in (2a)-(2d):

2. We include secondary stress as the input to the tableau for expositional purposes, remaining agnostic as to whether this is the result either of underlying assignment, or the presence of a constraint not shown in this tableau, or the output of an earlier stratum of phonological computation (as secondary-stress has a post-lexical character in BP; Collischonn 1994). 
(2) Prominence Scales employed in Augmentation

a. diphthongs $>$ simplex nuclei

b. complex onsets $>$ onsetful $>$ onsetless

c. nasal vowels $>$ oral vowels

d. low vowels $>$ mid vowels $>$ high vowels

The scales in (2) can be derived from a combination of increased duration for all of these, as is clearly true for cases of more segmental material (2a-b), and has been phonetically demonstrated for (2c) by Moraes \& Wetzels (2003) and for the vowel scale in (2d) by Crosswhite (1999). We contend that the phonologized effects of weight are stated in terms of weight-sensitive comparisons in phonological terms, although they phonetically derive from increased duration.

\section{Prominence-Demanding Positions in Brazilian Portuguese}

As is generally known throughout the Romance languages, main stress on all lexical items besides verbs (which are outside the scope of this study) falls within a three-syllable window from the right edge, enabling minimal triplets (e.g. sábia 'sage', sabia 'knew-imperf.', sabiá 'thrush'), with penultimate stress being the default. Final stress occurs predictably when the final syllable is heavy, ending in a glide or rhotic (e.g. ane [w] 'ring', abajur 'lampshade', hero[j] 'hero'). This quantity-sensitivity, discussed by Bisol (1992) and Wetzels (2007), does not always hold for final sibilants, which is what compels glide epenthesis.

The productivity of these principles, as discussed by Hermans \& Wetzels (2012) can be found in new coinages such as acronyms and pharmaceuticals, which follow these principles blindly. None of these bear orthographic accents; the accents shown below indicate where stress is assigned phonologically:

(3) Novel formations showing adherence to Main-Stress Assignment

a. Final WSP: Detran, Procon, Funai, Susau, Benes, Proer, Varsul, Anpol, Efexor, Dorless, Beserol

b. Default penult otherwise: Óvni, Bradésco, Texáco, Úfba, Clopsína

c. Final epenthesis leads to penult: Fapéspi, Telprági, Valméti, Nisulídi

More spectacular cases come from blend first-names, which are a goldmine for study given the onomastic creativity of anthroponyms in Brazil: Gustavo+Maria = Gusmar, and the famous case of the six soccer players from the 1970 World Cup Tostão + Pele + Rivelino + Carlos Alberto + Gérson + Jairzinho yielding the first name Tospericargerja (born that year), whose unusual name bears no need for an orthographic accent because, as inventive as his parents were, his name still has default penultimate stress.

Given the Weight-to-Stress-Principle holding over final syllables, followed by penultimate stress as a default, exceptional lexically-marked stress is therefore any 
case of antepenultimate stress or any case of penultimate stress when the final is heavy. Indeed, antepenultimate stress is not only unproductive, but has a tendency to be levelled out to penultimate stress, as found in colloquial pronunciations such as (4), in which the medial vowel is deleted (see França 2009, among others):

(4) Examples of antepenultimate stressed words undergoing syncope to become default penutimate-stressed:
a. árvore ['ah.vo.rI] > arvre ['ah.vrI]
'tree'
b. abóbora [a.'bo.bo.re] > abobra [a.'bo.bre]
'pumpkin'
c. xícara [' 'ji.ka. re] > xicra [' 'ji.kre]
'teacup'
d. córrego ['ko.he.gv] > corgo ['koh.gv]
'creek'
e. estômago [if.' tõ.ma.gu] > estomgo [if.' tõ.gu]
'stomach'
f. ônibus ['õ.ni.bus] > onbus ['õj.bus]
'bus'
g. cônjuge ['kõ.zu.3I] > conge ['kõ.3I]
'spouse'

As Herman \& Wetzels (2012) point out, there are two sets of regular antepenultimate stress: those that involve a high vowel in a hiatus context causing throwback in (5), and those (Leo Wetzels, pers. comm, and Asaf Bachrach, pers. comm) with prestressing suffixes (or possibly pseudo-suffixes synchronically) in (6):

(5) Antepenultimate stress with high vowel + vowel sequences: ${ }^{3}$

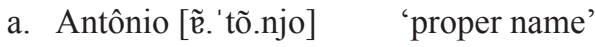
b. pátria ['pa.trje] 'homeland'
c. tábua ['ta.bwe] 'board'
d. Tânia ['tẽ.nje] 'proper name'

(6) Antepenultimate stress with prestressing sufixes -ico, -ido, -ula: ${ }^{4}$
a. elétrico [e.'le.trı.kv] 'electric'
b. plástico ['plas.tr.kv] 'plastic'
c. tímido ['fi.mi.do] 'timid'
d. rápido ['ha.pi.dv] 'rapid'
e. flâmula ['flẽ.mo.le] 'banner'
f. edícula [e.' 'dzi.kv.le] 'cottage'

3. In Portuguese orthography, antepenultimate stress is marked by an acute accent generally, but by a circumflex accent when a nasal vowel (i.e. before a nasal consonant).

4. Pseudo-suffixes of this sort may also be at play with anthroponyms such as Jéfferson, Éverton, with antepenultimate stress. 
Cases like (5) thus form an 'island of reliability' among the exceptions (although even the last two forms undergo sporadic glide metathesis, forming $t a[\mathrm{w}]$ $b a$ and $T a[\mathrm{j}] n a$ as an application of the SWP). The cases in (6) form a set of recurrent exceptions where high vowels repel stress recurrently with these formatives and may require only listing the (pseudo-suffixes) in question (-imo, ido, -ico, $-u l a, \ldots)$. Thus, while antepenultimate stress is lexical and exceptional, cases like (5-6) do seem to reduce the overall unpredictability given smaller pattern-governed cases within the exceptionality.

Now, what about secondary stress in BP? In general, secondary stress seems to be assigned separately (and perhaps after) the marking of primary stress. Thus, while there is variation among speakers in terms of whether a given lexical item has penultimate or non-penultimate stress for a handful of forms (e.g. rúbrica

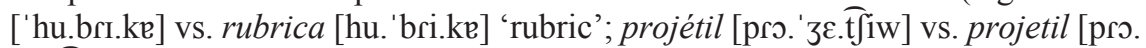

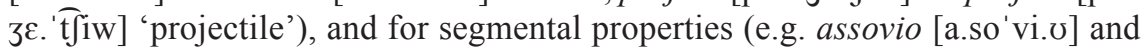
assobio [a.so'bi.o] 'whistle' are in free variation), there is no free variation between antepenultimate and final stress known for any form (say ássovio and assovió). Given the lack of much interspeaker variation in main stress, it is notable that there is indeed persistent variation in secondary stress, as pioneeringly discussed by Collischonn (1994); see also Buckley (2016) and Hualde \& Nadeu (2011) for related phenomena in Spanish. In English and Dutch, secondary stress can also be diagnosed by a syllable that is not a schwa (e.g. not a reduced vowel). Thus, English differentiates rái.der with [ə] vs rá.dàr, both with the same main stress but different secondary stress. In BP, secondary stress is diagnosable by relative prominence, though the acoustic correlates are complex (see Moraes 2003).

Importantly, as shown by Collischonn (1994), there are two strategies for assigning secondary stress, neither of which is apparently weight-sensitive. There is an initial dactyl strategy, found in words with an odd number of syllables before the main stress, and a rhythmic strategy.

(7) Variable Secondary Stress with Odd-Number of Pretonic Syllables:
a. maràcujá [ma., ra.ku.'za] màracujá [,ma.ra.ku. 'za]
'passionfruit'
b. abàcaxí [a., ba.ka.' 'fi] àbacaxí [, a.ba.ka.' Ji] 'pineapple'
c. Aràcajú [a., ra.ka.'zu] Àracajú [, a.ra.ka.'zu]
(toponym)

According to Collischonn, these are optional, automatic, and post-lexical, and even affected by late fast speech rules such as glide formation. Thus tetrasyllabic in.vi.á.vel [ĩ.vi.'a.vew] 'unviable' has initial secondary stress, whereas trisyllabic in.vjá.vel [ĩ.' 'vja.vew] does not, and pentasyllabic ro.(dò.vi)(á.rja) [ho,do.vi.'a.rje] 'bus station' has secondary stress on $d o$, whereas tetrasyllabic (rò.do)(vjá.rja) [, ho. do.'vja.rje] has it on $r o$.

Parallel work on Spanish, e.g. by Buckley (2016), has suggested that an initial dactyl is a possible footing strategy to achieve initial prominence, but in fact, considering even longer words opens the possibility that a ternary dactyl is simply a permitted foot-type in the inventory of secondary-stress feet. Thus the heptasyl- 
labic city (originally multimorphemic in its Tupi-Guaraní source, but not analyzed as such in BP) in São Paulo is (İ.ta).(qùa.que.ce).(tú.ba), with secondary stress on the first and third syllables, and main stress on the sixth. Interestingly, with even-numbered pretonic syllables, there is no room for such variation, and thus the derived demonym is an İ.ta.qùa.que.cè.tu.bén.se, with secondary stress on the first, third, and fifth syllables, and main stress on the seventh. Derived demonyms themselves, however, can exhibit medial dactyls, as in A.ràcaju.én.se, in which the second syllable alone has secondary stress, and the main stress falls on the fifth syllable. ${ }^{5}$

A final factor to consider in secondary stress is its apparent reassignment in cases of stress clash. Like English thirtéén vs thirteen mén or Tennesséé vs Ténnessee Williams, BP disallows stress clash caused by adjacent words (or compounding-suffixes): café 'coffee' càfezínho 'coffee-dim.' (and not cafézínho); see Sandalo \& Truckenbrodt (2002) for phrasal examples. But is this retraction, or simply erasure of the stress altogether, and reassignment based on Initial Dactyls? There is evidence that it is erasure + reassignment: ${ }^{6}$

(8) Variable secondary stress following stress-clash reassignment:
a. picolé [.pi.ko.' 'le] 'popsicle'
b. picòlezínho [pi ko.le'zĩ.no] 'popsicle-dim.', rhythmic trochee pattern
c. pìcolezínho [,pi.ko.lk'zĩ.nu] 'popsicle-dim.', initial dactyl pattern

With this overview of secondary stress assignment, we can now delimit the set of prominence-demanding positions in BP as those with main stress, those with secondary stress, where secondary stress is assigned by either rhythmic counting leftward from the main stress (always found in cases of an even-number of pretonic syllables), or in case of an odd-number of pretonic syllables, variation between the rhythmic pattern and use of dactyls (either medial or initial). There is, however, one additional position we must add to the inventory of prominence-demanding syllables, going above and beyond those resulting from foot structure, and that is the word-initial syllable itself.

The word-initial syllable, we contend, is a crucial site for prominence boosting, even if not directly footed as a locus of secondary stress. Many articulatory studies have found prominence boosting of segments at the edges of initial domains, as distinct from that of stressed syllables; see Fougeron (2001) and Cho \& Keating (2009). We appeal to the findings of Smith (2005) that the initial position is one that requires prominence-boosting for the psycholinguistic purposes of lexical access and word-recognition, in addition to potentially for reasons of speech planning by the speaker. For phonologically-based studies of the importance of the initial syllable, see Beckman (1998) and Becker et al. (2018), among many others.

5. Medial dactyls can also be observed as the result of phrasal footing, e.g. Peço vocês encarecidamente [('pe.so.vo)('ses.en.ca)('re.ci.da)('men.te)] 'Ask.1sg. you.pl warmly'.

6. We thank Leo Wetzels for suggesting this generalization. 
Summarizing this section overall, we expect prominence-boosting processes to affect (and not affect) the following syllables:

(9a) Syllables potentially demanding prominence-boosting:
i. Main stress $^{7}$
ii. Secondary Stress
iii. Initial Syllable

(9b) Syllables never demanding prominence-boosting:

i. Non-initial syllables with no secondary stress

Thus, consider the frequently described phenomenon of pretonic mid-vowel lowering in Northeastern dialects of Brazilian Portuguese (as described in oversimplified terms in Nevins (2012), for example). As the careful study of Santana (2019: 204) shows, this mid-vowel lowering does not in fact affect all syllables, but only secondary-stressed or initial ones. Thus, for a word like televisão 'television' with two pretonic mid-vowels, we expect the following possibilities, given the variability in secondary-stress and footing outlined above:

(10) Possible and Impossible Patterns of Prominence Boosting in NE BP:

a. Prominence-Boosting on head of initial dactyl and initial syllable: (ț̀̀.le.vi)são

b. Prominence-Boosting on head of $\mathrm{R}>\mathrm{L}$ trochee and initial syllable: t $\varepsilon($ lè.vi)são

c. Impossible pattern: (9a) with lowering of second, non-head: (ṫ̀.le.vi)são, or (àpe).(lí.do) 'nickname'

This concludes the overall outline of the patterns to be described in this paper: we have (a) a set of prominence-boosting positions, (b) a set of prominence-needy syllable types, and (c) a set of processes that seek to boost syllables that fall in both (a) and (b). Thus, in (10), the prominence-boosting positions are those of initial position and/or secondary stress, the prominence-needy syllables are those with lower sonority (e.g. closed mid-vowels), and the process to achieve prominence-boosting is mid-vowel lowering, a process specific to Northeastern BP and outranked by constraints on faithfulness in other dialects of Portuguese.

7. Interestingly, Brazilian Portuguese final syllables headed by underlying /i/ or / $\mathrm{u} /$ typically attract stress, e.g. bambú 'bamboo', sushi 'sushi'. This typologically surprising attraction of stress to low-sonority nuclei may be related to differentiating them from the underlying /e,o/ that post-tonically reduce to $[\mathrm{I}, \mathrm{v}]$ and are never stressed. In fact, words with final /i/ without final stress, e.g. táxi 'taxi' may even be analyzed by speakers as with an underlying /e/, as found in the possible vocative form [tak.se]. Whatever the analysis of stress-attracting final $/ \mathrm{i}, \mathrm{u} / \mathrm{may}$ be, it is noteworthy that no examples of spontaneous nasalization in our corpus are found with such vowels. Presumably, in final open syllables, they have enough prominence on their own, without nasalization (though nota-

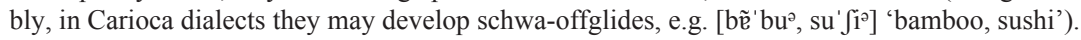


A similar pattern to (10) can be found in rhotic metathesis in the Romance languages; thus, there is alternation between crocodillo and cocodrillo 'crocodile' showing variation between stressed syllable and initial syllable, whereby medial unstressed syllable is never touched (see Damulakis 2005: 66). This kind of rhotic metathesis is found in non-standard forms in BP (and for coda cases such as 11d, seems to hold independently of whether the rhotic realization is retroflex, velar fricative, or glottal fricative):

(11) Rhotic metathesis to the primary/secondary stressed-syllable
a. ['vi.dro] $>$ ['vri.dv]
'glass'
b. [if.'tu.pro] $>$ [if.' tru.pv]
'rape'
c. [fits. 'pe.trI.kI] $>$ [fits. 'pre.tr.kI]
('Fitzpatrick' proper name)
d. [, la.gah'tfi.fe] $>$ [, lah.ga'tfi.fe ]
'lizard'

There is ample documentation of the diachronic phenomenon of rhotacism in Portuguese (e.g. branco 'white', compare Spanish blanco and French blanc) which is often colloquially extended to newer words (e.g. Leblon > Lebron 'toponym'). The reason for such substitution, often not explicitly commented upon, is arguably to improve the sonority profile of the onset, as $/ \mathrm{r} /$ is more sonorous than $/ 1 /$ (and indeed, this feeds into the restriction that $[\mathrm{tl}, \mathrm{dl}]$ are banned as word-initial onsets while [tr, dr] are allowed; see Moreton 2002 for pertinent discussion from English, and Pons-Moll 2008 for the proposal that taps are more sonorous than laterals in Romance). Rhotacism is so common it often overshadows the arguably distinct, stress-related phenomenon of rhotic metathesis: the migration of the $/ r /$ from a complex onset in an unstressed syllable into that of a stressed syllable. The cases reviewed herein are entirely non-standard and have not been treated in diachronic literature on Portuguese, as they are sporadically found, and unattested in standard variants. Consider moreover the oft-noted example problema > pobrema 'problem'. While this may have the appearance of 'rhotacism', this would not explain the disappearance of the $/ \mathrm{r} /$ in the first syllable. Similarly, wholesale liquid metathesis (of the kind found in miraklo > milagro 'miracle') is not at stake as the form is not plobrema. Instead, what is happening is that the unstressed syllable is robbed of its rhotic, as an unstressed syllable is not allowed more prominence than a stressed one. Thus, we treat problema $>$ po 'brema as a case of metathesis to the stressed syllable.

Similarly, Lipski (1992a) who collects examples from Spanish such as fábrica $>$ frábica 'factory' and dentro $>$ drento 'inside', as well as initial-syllable transpositions like petróleo > pretóleo 'petroleum', mentions (p. 100) “This apparent leftward skewing of consonant clusters may have to do with relative prominence, articulatory energy, or the position of the stress peak within the word." Clàudia Pons-Moll (pers. comm) cites examples from Majorcan Catalan such as padri $>$ pradi, which depart from the stressed syllable, but crucially move to the initial syllable. While examples of leftward metathesis by only one syllable are found (as metathesis is often sporadic), we contend that, parallel to (10), rhotic metathesis can 
be to a primary/secondarily stressed syllable, or to the initial syllable, but is less likely to migrate to a non-initial, unstressed syllable. Rhotic metathesis is widely discussed for the Iberian languages, but here we limit our attention to BP, where it manifests itself as a prominence-augmentation phenomenon.

In a tellingly parallel fashion, Blevins \& Garrett (1998) cite the example of Bagnères-de-Luchon, for which "Posttonic $r$ has moved one syllable to the left, into the historically stressed syllable (which is often also the initial syllable)." The analysis they posit is exactly within the spirit adopted here: "In addition, long-distance movement processes evidently move segments or features into syllables which are in some sense more prominent: stressed syllables, as in Colville; or initial syllables, as with Bagneres-de-Luchon French and Ancient Greek. We cannot fully explain these patterns, but they are consistent with the view that the segments and features in Table 1 occupy long durational windows which allow for their reinterpretation in nonhistorical positions. This perceptual reinterpretation involves segments and features which are drawn to positions of prosodic prominence." (p. 527).

Rhotic metathesis is thus already discussed in the literature as a case of prominence-augmentation, and we contend that the nasal vowel metathesis found in (1) above is exactly parallel to such cases. In what follows, we turn to spontaneous nasalization - the introduction of nasal vowels in non-etymological positions, with the same motivation, but in cases for which no existing nasal vowel can be said to have been transposed. Such cases, to our knowledge, are not found with rhotics (e.g. spontaneous insertion of rhotics as the second member of an onset cluster).

\section{Spontaneous Nasalization as Prominence-Augmentation}

We repeat below the prominence scales from (2):

(2) a. diphthongs $>$ simplex nuclei

b. complex onsets $>$ onsetful $>$ onsetless

c. nasal vowels $>$ oral vowels

d. low vowels $>$ lower-mid vowels $>$ upper-mid-vowels $>$ high vowels

Many authors (especially Smith 2005) have proposed that certain phonological processes can be understood in terms of prominence augmentation, especially when initial or secondarily-stressed syllables do not have sufficiently prominent segmental material. Many phenomena, both within standard and non-standard varieties of BP, can be understood within this logic. For example, Wetzels' (1997) neutralization of mid-vowels to the lower, [-ATR] version in proparoxytones (dactylic lowering) and in penultimate-stressed words that violate the Final-WSP (spondaic lowering) is once such case, motivating the distribution of this vowel in $m$ [o] vel 'furniture', $a b[0]$ bora 'pumpkin', $d[\mathrm{o}]$ lar 'dollar', [o]rfã 'orphan', $F[\varepsilon]$ lix 'proper name', Pers[E]fone 'proper name' and so forth. Once we view vowel height as a kind of sonority that increases the prominence of a syllable, these marked foot-types receive greater sonority in the head position, again using the logic of CoINCIDE as defined in Zoll (1998), as shown in the tableau in (13) for dactylic lowering. 
(12) Definition of Coincide family of constraints

CoINCIDE (strong position, prominent property)

(i) $\forall x(x$ is a strong position $\exists y(y=$ prominent property $\mathrm{v}$ Coincide $(x, y)) \cdot$ Coincide $(x, y)$ will be true if $y=x, y$ dominates $x$, or $x$ dominates $y$

(ii) Assess one mark for each value of $x$ for which (i) is false.

We can now apply this to the position Head-Dactyl, as a prominence-augmenting position. In terms of why the head of a dactyl should be a prominent position, consider the representations in Martínez-Paricio \& Kager (2015) and in Hermans \& Wetzels (2012), according to which the head of a dactyl, in a recursive binary representation, is the head of a head of a foot, and hence doubly strong.

(13) Tableau for Dactylic Lowering: ${ }^{8}$

\begin{tabular}{|r|c|c|c|}
\hline$/$ per('se.fo.nI)/ & $\begin{array}{c}\text { CoINCIDE(Head-Dactyl, } \\
\text { [-ATR] })\end{array}$ & DEP [+low] & DeP [-ATR] \\
\hline [per('se.fo.nI)] & & & $*$ \\
\hline$[$ per('se.fo.nI)] & $* !$ & & \\
\hline$[$ per('sa.fo.nI)] & & $* !$ & \\
\hline
\end{tabular}

The collection of spontaneous nasalization data in BP we analyze here is based on Costa (2019), and composed of 219 examples in which nasalization occurs in positions that deviate from the etymological and/or standard forms of such words in BP. The data are based on written forms collected from social media and blogs. While one might protest that written forms are not revealing, the fact is that one does not always have a recording device handy while spontaneous nasalization is uttered. Nonetheless, the existence of non-etymological nasalization in BP forms such as indioma 'language', ingreja 'church', indiota 'idiot', indentidade 'identity', ingnorante 'ignorant' are widely known to all speakers of the language, even if dismissed as mere errors. Souza e Melo (2015) collected written data from ninthyear students in the city of Recife, and reports that she "has observed as a teacher that this kind of nasalization is very widespread among students" (p. 79, translation ours); see also passing mentions in Marroquim (2008: 47). ${ }^{9}$ Alves (2004), working

8. As mentioned earlier, we include secondary stress (and footing) as the input to the tableau for expositional purposes, remaining agnostic as to whether this is the result of a constraint not shown in this tableau, or the output of an earlier stratum of phonological computation (as secondary-stress has a post-lexical character in BP; Collischonn 1994). See also footnote 12 for suggestive evidence that spontaneous nasalization is a process with a late character, following the determination of rhotic allophony.

9. Such forms are also frequently commented upon in blogs, e.g. $<$ http://mixdereferencias.blogspot. $\mathrm{com} / 2016 / 12$ palavras-erradas-que-parecem-certas.html $>$ (accessed 1 June, 2019). At the moment, we have only conducted a thorough study of this phenomenon in Brazilian varieties of Portuguese. According to Ezra Champal Nhampoca (pers. comm), Mozambican varieties with extensive contact 
on the quilombo Portuguese of Gurutubana, Minas Gerais, notes the recurrence of "spurious nasalization" in word-initial position and with the vowel /i/ (p. 21).

Cases of nasal epenthesis with initial onsetless [i] in fact have some diachronically enshrined cases, the most famous being Latin hibernum, which became inverno in Spanish and Portuguese. ${ }^{10}$ While most of the well-known examples cited above start with a word-initial onsetless high front vowel, this is by far not the only set of such cases (and indeed, it is difficult to claim that these all have negative connotations from a pseudo-prefix in- as this would be unlikely for the cases of 'church' and 'identity'). All written sources were taken from ones with more than 50 non-repeated hits, and the top hits were verified as ones with a clear author who was a speaker of Portuguese. In addition, to make sure that these patterns were not purely due to orthotactic trends (e.g. word-initial $<$ in $>$ sequences), Costa (2019) collected audio samples in individual recordings, in which specific words were targeted by means of elicitation and interviews, largely with interviewees without university-level education, which we contend inhibits this kind of spontaneous nasalization, an otherwise natural and understandable trend given the phonology of the language, but one that is stigmatized when a 'known' form exists - unlike the very case with which we began this article. The following is a sample of spontaneous nasalization as found in Costa (2019): ${ }^{11}$ the full set occurs in the appendix.

(14) Examples of Spontaneous Nasalization via Epenthesis:

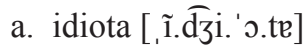
'idiot'
b. igreja [ĩ.' gre.ze]
'church'
c. ironia [, ĩ.ro. 'ni.e $]^{12}$
'irony'

with Bantu languages such as Changana may exhibit non-etymological nasality, e.g. enconomia 'economy'. European Portuguese is likely to maintain a different system of nasalization, as apocope can generate the existence of emerging minimal pairs such as com [kõ] 'with' vs kone [kõn] '(sushi) cone', potentially yielding a system like contemporary French.

10. Interestingly, hibernar was re-borrowed from Latin with the meaning 'to hibernate', and this item has re-undergone spontaneous nasalization in our sample: [,i.beh.' nah].

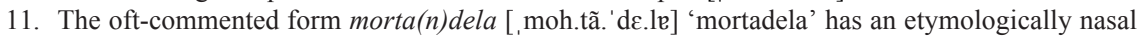
source, as it appears as a variant in Italian itself (see $<$ https://www.ildolomiti.it/societa/2018/ la-storia-della-mortandela-orgoglio-della-val-di-non>, accessed 1 June 2019).

12. Mattoso Câmara Jr. (1970) assumes that nasal vowels pattern like closed syllables with a coda consonant, thereby explaining why the distribution of rhotics in BP - in particular, the 'strong', or fricative rhotic (as opposed to the tap) does not occur after a closed syllable, as in Israel 'Israel', enredo 'storyline', Henrique 'proper name', honra 'honor', genro 'son-in-law'. However, our collection of spontaneous nasalization includes [ĩ. 'ra.dv] 'irate' and [,ũ.ru. 'gwaj] 'Uruguay', in which nasalized vowels precede the tap. These could be taken to suggest either that Mattoso Camara's generalization that nasalized vowels are equivalent to closed syllables is not absolute (perhaps as already challenged by the existence of the proper name of a soccer player Dãr.ley), or that the spontaneous nasalization under scrutiny in this paper is a 'late' process, imposed after the determination of rhotic allophony. Of further relevance to the question of timing of rhotic allophony are the facts noted by Leo Wetzels (pers. comm), that while the fricative rhotic is largely not found after diphthongs, the process of 1-vocalization can create such sequences for words such as melro 'blackbird', guelra 'gill', or bilro 'bobbin', which yield a diphthong before the fricative rhotic. 
d. usufruir [ũ.,zu.fru. 'ih] 'to make use of'

e. ebulição [ĩ., bu.li. 'sãw] 'boiling'

f. ocorrer [õ.ko.' heh] 'occur'

g. abacaxi [ã.,ba.ka.' $\left.\int \mathrm{i}\right] \quad$ 'pineapple'

h. afligir [,a.flĩ.'zih] 'to ail'

i. $\operatorname{aipim}[$ a.i..'pĩj] 'yucca'

j. pichação [.pĩ.fa.'sãw] 'grafitti'

k. pudim [pũ.'dĩj] 'pudding'

1. cobaia [kõ.'baj.je] 'guinea pig (i.e., test case)'

Ideally, these data points can all be evaluated in a perceptual study - in a same/ different or ABX task, or one in which participants rate the degree of deviation amongst two pronunciations - to see how acceptable and/or perceptually salient these are (and potentially with pseudo-words as well).

Of 219 total examples of spontaneous nasalization, 182 of them $(83 \%)$ occurred in the initial syllable. A breakdown by vowel quality is found below: ${ }^{13}$

(14) Spontaneous Nasalization targets, by individual vowel

\begin{tabular}{|c|c|c|}
\hline Vowel & Occurrences & \% \\
\hline $\mathbf{i}$ & 175 & $80 \%$ \\
\hline $\mathbf{u}$ & 18 & $8 \%$ \\
\hline $\mathbf{e}$ & 10 & $5 \%$ \\
\hline $\mathbf{0}$ & 11 & $5 \%$ \\
\hline $\mathbf{a}$ & 5 & $2 \%$ \\
\hline Total & $\mathbf{2 1 9}$ & \\
\hline
\end{tabular}

As can be verified, there is an extremely high rate of occurrence for [i], followed by $[\mathrm{u}]$, though nearly ten times less. While one might generalize specifically to [i] as opposed to high vowels specifically, it is important to recall that in BP, the overall distribution of [i] is much higher than that of [u], and even more pronounced in initial position (where words like umbigo 'navel' are often non-standardly pronounced as imbigo). Summing up [i] and [u] with the caveat that $[\mathrm{u}]$ is rarer to begin with, high vowels make up $88 \%$ of the total targets of spontaneous nasalization. (See Cedergren \& Sankoff 1975 for a similar rate of vowel nasalization of high vowels vs non-high vowels in Panamanian Spanish). In fact, Hajek \& Maeda (2000) report that "at low levels of velic opening, nasalization is likely to be perceptually more salient in high vowels". They reanalyse the oft-cited diachronic height hierarchy of nasalization, bringing many counterexamples to the fore, and concluding

13. Onsetless initial /e/ (or at least, etymological/orthographic $<\mathrm{e}>$ ) is very frequently reduced to [i], particularly when nasalized or preceding sibilants. 
that the oft-noted effect of low vowels is often brought about by increased duration, and that when duration is controlled, studies such as House \& Stevens 1956 find that "synthetic low vowels require almost three times as much velic opening as high vowels before they are identified as nasal by American listeners".

As for the front-back asymmetry found in BP, this is in fact consistent with an assertion made by Ohala (1975), who suggests that given two vowels with similar F1 values, those with higher F2 values are easier to nasalize. ${ }^{14}$

The epenthesis of nasalization on an initial, onsetless high vowel is shown below, using an adaptation of COINCIDE specific to this position: ${ }^{15}$

(15) Tableau for Epenthetic Nasality in Initial, Secondary-Stressed Position

\begin{tabular}{|c|c|c|c|}
\hline /i.di.o.ta/ & CoInCIDE (NasalV) & DEP $[+$ nasal $]$ & *NasalV \\
\hline [.1. $\widetilde{\mathrm{d} z} \mathrm{i}$ i.'o.te] & & $*$ & $*$ \\
\hline 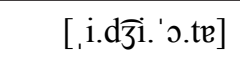 & $* !$ & & \\
\hline
\end{tabular}

The same process of prominence-boosting occurs below, in which spontaneous nasalization is found in the initial syllable - even if not secondarily-stressed:

(16) Tableau for Epenthetic Nasality in Initial Position

\begin{tabular}{|c|c|c|c|}
\hline /i.' gre.ze/ & CoINCIDE $\left(\sigma_{1}\right.$, NasalV) & DEP [+nasal] & *NasalV \\
\hline [ĩ.'gre.3e] & & $*$ & $*$ \\
\hline [i. 'gre.ze] & $* !$ & & \\
\hline
\end{tabular}

As for the high vowel effects, these could be captured by a family of Coincide constraints specific to each vowel height, with Dep(Nasal) interleaved in terms of tolerance, as shown for example in (17):

(17) Height-Specific Rankings for Prominence-Boosting Nasalization:

CoInCIDE $\left(\sigma_{1}\right.$, NasalV $_{\text {high })}>>$ DEP $\left[+\right.$ nasal $>>$ CoINCIDE $\left(\sigma_{1}\right.$, NasalV $\left._{\text {mid }}\right)>>$ $\operatorname{CoInCIDE}\left(\sigma_{1}, \mathrm{NasalV}_{\text {low }}\right)$

As can be observed in the examples in (14), the majority of these examples involve prominence-boosting on an initial syllable, a secondary-stressed syllable, or a stressed-syllable (and moreover, usually a high vowel, and in fact an onsetless

14. In terms of the following consonant, $41 \%$ of the $219 \mathrm{BP}$ cases of spontaneous nasalization occurred before fricatives. As discussed by Ohala \& Busà (1995), the airflow required by fricatives causes articulatory opening and subsequent ambiguous perceptual effects that can either lead to nasal deletion before fricatives (e.g. gans $>$ goose in English) or nasal insertion (e.g. bonaça $>$ bonanza in Spanish).

15. In this paper, we adopt the position that nasal vowels involve addition of the feature [ + nasal], though this is perfectly compatible with this being the result of addition of a coda nasal that triggers regressive nasalization. 
high vowel). Lipski (1992b) contains a number of parallel examples from AfroHispanic bozal Spanish, as listed below, which he contends represents "the addition of a [+nasal] autosegment to the beginning of certain words" (p. 264).

(19) Spontaneous Nasalization in Bozal Spanish:
a. suplica $>$ sumprica
'begs'
b. ripito $>$ rimpito
'rhythm'
c. despachar $>$ dimpachá
'to send'
d. repica $>$ rimpicá
'to chime'
e. iglesia $>$ ingresia
'church'
f. ofrece $>$ unfrece
'offer'

Lipski (1992b: 285) concludes that these "apparent word-internal nasal consonants, added syllable-finally, in reality represented vowel nasalization, possibly combined with low-level epenthesis of an occlusive nasal element before the following consonant".

Let's now consider the breakdown by stress in BP:

(20) Spontaneous nasalization within sample, breakdown by stress

\begin{tabular}{|l|c|c|}
\hline \multicolumn{1}{|c|}{ Stress level } & Occurrences & \% \\
\hline Primary stress & 24 & $11 \%$ \\
\hline Secondary stress & 83 & $38 \%$ \\
\hline No stress & 112 & $51 \%$ \\
\hline Total & $\mathbf{2 1 9}$ & \\
\hline
\end{tabular}

As can be seen, primary stressed cases are the least type-frequent (although

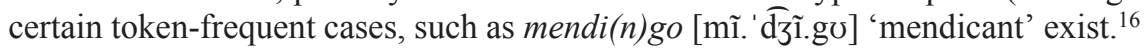
Some of these may be chalked up to a tendency for harmony, such as $n i(n)$ cho 'niche', which is so commonly used in this form that it may be changing in the language, and related phonologically-triggered instances may be due to aggressive reduplication (in the sense of Zuraw 2002 for non-etymological cases of insertion such as sherbert) with an existing syllable with nasality already present. In order to model the fact that speakers resist spontaneous nasalization on a primary stressed syllable, IDENT( \pm nasal)- $\sigma$ would outrank all of the relevant CoINCIDE constraints.

Secondary-stressed ones make up a significant percentage, cases such as ve.i(n) cu 'lar [ve.,i.ku. 'lah] 'to convey'. However, for some of these, given the remarks above that secondary stress is variable, we cannot be fully certain that the version

16. A potential etymology offered for the word gringo 'foreigner' for Spanish involves an epenthetic nasal in the word griego 'Greek', accompanied by reduction of the diphthong. See Sayers (2009) for extended discussion. 
with spontaneous nasalization indeed was rendered with secondary-stress on the nasalized syllable.

Finally, let us consider the completely non-accented ones. Of these, how many are in the initial syllable? $88 \%$, as can be seen below, greatly confirming the tendency already reported and modelled by CoINCIDE $\left(\sigma_{1}\right.$, NasalV).

(21) Spontaneous nasalization in the 112 unstressed syllables, breakdown by syllable position

\begin{tabular}{|c|c|c|}
\hline Position & Occurrences & \% \\
\hline$\sigma_{1}$ & 98 & $88 \%$ \\
\hline$\sigma_{2}$ & 13 & $12 \%$ \\
\hline$\sigma_{3}$ & 1 & $1 \%$ \\
\hline Total & $\mathbf{1 1 2}$ & \\
\hline
\end{tabular}

As this table shows, the overwhelming majority of cases of spontaneous nasalization in the initial syllable occur when it is unstressed. Of the thirteen items with an unstressed non-initial syllable, one is aim.pim 'yucca', most likely a case of aggressive reduplication in Zuraw's sense (e.g. sporadic occurrences of sancrosanct in English, or Ur.ber for 'uber' in BP) ${ }^{17}$, and the other is mortandela 'mortadela'; see footnote 11 for discussion of this case. There are potentially thus even fewer.

Summing up, therefore, constraints such as CoINCIDE $\left(\sigma_{1}\right.$,NasalV) are intended to guarantee that spontaneous nasalization will be attracted to the initial syllable, and its height-specific family of subconstraints to those with high vowels. The guiding intuition is that nasalization increases prominence, and that the initial syllable, and specifically when it is a shorter-duration high vowel, needs this increased prominence. For durational data on pretonic high vowels vs non-high vowels, see Faveri (1991) and Moraes (1999), both of whom found pretonic high vowels to be up to $40 \%$ shorter than the non-high vowels. Indeed, as mentioned in footnote 7 , variants of the Carioca dialect of BP specifically enhance stressed high vowels

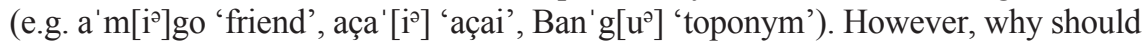
nasal epenthesis (or metathesis) occur more with onsetless initial syllables? We turn to this last issue in the final section.

\section{Nasality as a Contributor of Weight}

Before proceeding, we wish to include here some novel data from a study of Brazilian Portuguese loanwords as adapted into Maxakalí, an indigenous MacroJê language spoken in Minas Gerais, Brazil, as reported in Silva et al. (2019).

17. A related case in an initial syllable is sobrancelha 'eyebrow', which has both the variants sombracelha, with metathesis (perhaps affected by the existing lexeme sombra 'shadow'), and sombrancelha, with epenthesis; the latter case perhaps may be analyzable as aggressive reduplication. 
(22) Spontaneous Nasalization in Initial Onsetless High Vowels in Maxakalí Loanwords
a. açúcar
[a'sukəh] $>$ [ã't t6ou $]$
'sugar'
b. espelho

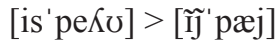
'mirror'
c espora
[is 'porə] > [ก̃]' puə]
'spur'
d. Oliveira
[oli'verə] > [ũnĩ'beə ]
(proper name)

While the authors treat this phenomenon as the result of a constraint specific to the native language, *\#OrALV, the question immediately arises as to why Maxakalí, too, disprefers onsetless oral initial syllables (particularly as the examples above are not found in Pinheiro's corpus of BP forms with spontaneous nasalization).

It is already known that pretonic high vowels are shorter than pretonic nonhigh vowels (see above; Faveri 1991 and Moraes 1999). It is also known that nasal vowels are longer than their non-nasalized counterparts (Moraes \& Wetzels 1992). Finally, onsetful syllables are naturally longer than onsetless syllables, by virtue of having more segmental material.

Thus, following the work of Topintzi (2010) and Ryan (2014), let us consider onsets as contributing to syllable weight, and following that of Moraes \& Wetzels, let us consider nasal vowels as bearing an additional unit of weight as compared to their oral counterparts. It would be straightforward to have a version of the SWP as follows for a word such as $i(n)$ çar 'to hoist' which undergoes spontaneous nasalization. Coincide would require two moras, which could be satisfied either by [ + nasal] epenthesis or by onset epenthesis, with the later considered costlier.

(23) Initial Tableau for Nasal Epenthesis as Weight Satisfaction

\begin{tabular}{|c|c|c|c|}
\hline /i.'sah/ & $\operatorname{CoINCIDE}\left(\sigma_{1}, 2 \mu\right)$ & DEP (Cons) & $\operatorname{DEP}(+$ nasal $)$ \\
\hline [ĩ.'sah] & & & $*$ \\
\hline [i.'sah] & $* !$ & & \\
\hline [ti.'sah] & & $* !$ & \\
\hline
\end{tabular}

The problem with this style of analysis is that it would mean syllables with an onset consonant and a nasal vowel would have three moras. At this point, we arrive at a theory with potentially more weight distinctions than are required for stress assignment and quantity-sensitivity per se. This immediately brings us to the gradient model of Brazilian Portuguese stress in Garcia (2017), similar to the gradient model of weight presented in Ryan (2014). In such a model, specific gradient values are assigned to onsetful vs onsetless syllables and to those with coda consonants / nasalization. In the absence of specific numerical values at present, we can abstractly formalize a scale as in (24), leading to the revised tableau in (25): 
(24) Gradient values of weight contribution

a. Onsets contribute an amount Wo of syllable weight; Nasalization contributes an amount $\mathrm{W}_{\mathrm{N}}$ of syllable weight, where potentially $\mathrm{W}_{\mathrm{N}} \neq \mathrm{W}_{\mathrm{O}}$

b. Vowels bear an inherent amount of weight $\mathrm{W}_{\mathrm{v}}$, a function of their height

c. The total weight of a syllable is thus $\mathrm{W}_{\mathrm{v}}+\mathrm{W}_{\mathrm{N}}+\mathrm{W}_{\mathrm{O}}$

c. Let $\mathrm{W}_{\mathrm{v}}+\mathrm{W}_{\mathrm{N}}=\mathrm{W}_{\mathrm{T}}$, a threshold for sufficient prominence for initial syllables

(25) Revised Tableau for Nasal Epenthesis as Weight Satisfaction

\begin{tabular}{|c|c|c|c|}
\hline$/$ i. 'sah/ & $\operatorname{CoInCIDE}\left(\sigma_{1,} \mathrm{~W}_{\mathrm{T}}\right)$ & DeP (Cons) & $\operatorname{DeP}(+$ nasal $)$ \\
\hline$[$ ĩ. 'sah] & & & $*$ \\
\hline [i. 'sah] & $* !$ & & \\
\hline [ti. 'sah] & & $* !$ & \\
\hline
\end{tabular}

More refined models of gradient stress, such as those in Garcia (2017), who adopts a logistic regression, though without specific constraint formulations, would be needed to confirm these with specific durational values, ideally in a manner akin to that developed in Ryan (2014) for gradient onset weight.

In closing, we note that although onsets themselves are never inserted wholesale, rhotic metathesis does occur, by hypothesis, to increase the prominence according to the second member of a branching onset. DEP(Cons), therefore, might be more ideally formulated in terms of insertion of a prosodic onset node, and when one already is present, the metathesis of a rhotic to its second position is less intrusive. In a sense, these results support the split margin hypothesis of Baertsch \& Davis (2003) that the second position of an onset and the coda have something in common - in BP, both can be mustered to increase syllable weight. Let us consider an amendment of (24) with the split margin hypothesis:

(26) Gradient values of weight contribution with the Split margin hypothesis

a. Initial Onsets contribute an amount Wo of syllable weight

b. A coda consonant (and nasalization) contributes the same amount of syllable weight as the second member of an onset, both being margins contributing an amount $\mathrm{W}_{\mathrm{M}}$ of syllable weight, where potentially $\mathrm{W}_{\mathrm{M}}>\mathrm{W}_{\mathrm{O}}$

b. Vowels bear an inherent amount of weight $\mathrm{W}_{\mathrm{v}}$, a function of their height

c. The total weight of a syllable is thus $\mathrm{W}_{\mathrm{v}}+\mathrm{W}_{\mathrm{M}}+\mathrm{W}_{\mathrm{O}}$

c. Let $\mathrm{W}_{\mathrm{v}}+\mathrm{W}_{\mathrm{M}}=\mathrm{W}_{\mathrm{T}}$, a threshold for sufficient prominence for initial syllables 
With the addition of (26b), we may consider one last interesting datum, observed by the authors, by a child acquiring BP who substituted nasalization for a complex onset. The word in question, dri blar, with a complex onset, was simplified (with rhotacism or rhotic metathesis to the stressed syllable). Removal of the rhotic placed the coronal stop and the high front vowel in contact, feeding affrication (see Cristófaro Silva et al. 2017 for phenomena of this sort in child $\mathrm{BP})$ to [dzi]. Most interesting, however, is the epenthetic nasalization that occurs [dzí'braf], by hypothesis as compensation for the loss of the second member of the onset, in order to preserve $\mathrm{W}_{\mathrm{T}}$ (the constraints compelling rhotic metathesis are not included in this tableau):

(27) Tableau for nasalization as compensatory weight addition in onset simplification

\begin{tabular}{|c|c|c|c|}
\hline / dri'blah/ & $\operatorname{CoINCIDE}\left(\sigma_{1,} \mathrm{~W}_{\mathrm{T}}\right)$ & *COMPLEXONS & DEP(+nasal $)$ \\
\hline 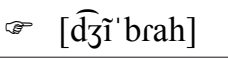 & & $*$ & $*$ \\
\hline 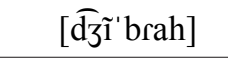 & $* !$ & $*$ & \\
\hline [dri'brah] & & $* * !$ & \\
\hline
\end{tabular}

While compensatory lengthening (i.e. rime augmentation) under loss of margin /r/ has been explored for Samothraki Greek by Topintzi (2010) and by Cristófaro Silva et al. (2017) for child BP, the case in (27) would be the first to our knowledge of the inverse, namely addition of margin coda (indicated via [+nasal]) to compensate for loss of onset weight. It also raises the question of other sources of coda epenthesis in BP for the sake of achieving $\operatorname{CoINCIDE}\left(\sigma_{1}, \mathrm{~W}_{\mathrm{T}}\right)$, and it may be that cases such as ur.ber 'Uber' occur instead of epenthetic nasalization specifically because nasal [ $\tilde{\mathrm{u}}]$ is extremely marked in BP, as mentioned above. Thus, summarizing with broad brushes the patterns of prominence augmentation, for the midvowels, spondaic lowering to [-ATR] (as in (13)) is available; for /i/, nasalization is preferred (as lowering any further would require more feature changes), and for /u/, where it occurs, rhotic epenthesis may be a strategy.

\section{Conclusions and future directions}

We have suggested that primary - and secondary - stressed syllables (and initial syllables) are like magnets, in drawing more segmental material toward them in order to enrich the asymmetry between them and unstressed syllables. The need for this additional segmental material arises most sharply with the durationally shortest syllables: high vowels, in onsetless syllables. Repair strategies include epenthesis or metathesis of nasality, mid-vowel lowering, and rhotic metathesis, all of which increase syllable prominence (duration, most acutely). Strategies such as glide insertion or raddoppiamento sintattico in Italian may also be seen as prominenceenhancement (and indeed, raise the question of whether non-etymological gemination in Italian forms such as repubblica occur quantitatively more often when the 
stressed nucleus that benefits durationally is a high vowel). Of course, there are cases of spontaneous nasalization outside of high vowels in onsetless initial syllables, but the quantitative predominance of the pattern we have identified is what we aim to capture through the analysis presented above.

A full theory of gradient weight must take into account not only the relative contribution - both phonologically and phonetically - of nasalization versus branching onsets (which we have argued may be in a compensatory relation), but also that of vowel height itself, and crucially how these factors all interact. Thus, future studies may benefit from greater exploration of the relatedness of spontaneous nasalization of word-initial vowels with the phenomenon of vowel lowering of word-initial onsetless vowels discussed in Jiménez \& Lloret (2013), according to whom Valencian Catalan lowers unstressed but word-initial espina, escala, entendre to aspina 'thorn', ascala 'stairs', antendre 'to understand', respectively. From this perspective, spontaneous nasalization in BP forms part of a much larger pattern of positional markedness within Iberian languages.

One of many final questions with which we wish to end is the relationship between vowel lowering (of the mid-vowels, as discussed above for Northeastern dialects) and nasalization. To our knowledge, these processes do not apply jointly. One might contend that either adding nasalization or enacting vowel lowering is enough, and that too many deviations from faithfulness are incurred by epenthesizing both marked features. On the other hand, this particular combination, namely [-ATR] mid vowels that are [+nasal], is generally ruled out in the phonology of Brazilian Portuguese. ${ }^{18}$ Nonetheless, a complete theory of gradient weight may be able to derive why nasalization or vowel lowering provide just the right amount of additional weight for prominence-boosting, without the need for applying both.

\section{References}

Alves, Diocles Igor Castro Pires. 2004. O processo de nasalização no dialeto quilombola Gurutubano. Masters' thesis, Pontifícia Universidade Católica de Minas Gerais.

Baertsch, Karen \& Stuart Davis. 2003. The split margin approach to syllable structure. ZAS Papers in Linguistics 32: 1-14.

Becker, Michael, Andrew Nevins, Filomena Sandalo \& Érick Rizzato. 2018. The acquisition path of [w]-final plurals in Brazilian Portuguese. Journal of Portuguese Linguistics 17.4: 1-17.

Beckman, Jill N. 1998. Positional faithfulness. Doctoral dissertation, University of Massachusetts Amherst.

18. In dialects found within the states of São Paulo and Paraná, however (Maximiliano Guimarães, pers.comm; Filomena Sandalo, pers. comm) there is however an 'island of reliability' in exceptionally allowing nasal [-ATR] mid vowels only with the back vowel [õ] in stressed syllables and only before [m] in words such as fome, nome [fõmI, nõmI] 'hunger', 'name', and even forming a minimal pair among verbs some [sõmI] 'sum up 3.sg' vs some [s̃̃mi] 'disappear (imper.)!', not distinguished in standard BP dialects. Spontaneous nasalization is not expected here, as these are allophonically nasal in any event; it is only their [-ATR] character that is unexpected. 
Bisol, Leda. 1992. O acento e o pé métrico binário. Cadernos de Estudos Linguísticos 22: 69-80.

Blevins, Juliette \& Andrew Garrett. 1998. The origins of consonant-vowel metathesis. Language 74.3: 508-556.

Borrelli, Doris. 2002. Raddoppiamento Sintattico in Italian. A Synchronic and Diachronic Cross-Dialectal Study. New York, London: Routledge.

Buckley, Eugene. 2016. Foot Alignment in Spanish Secondary Stress. In Jeff Heinz, Rob Goedemans \& Harry van der Hulst (eds.). Dimensions of Stress. Cambridge: Cambridge University Press, 79-100.

Câmara Jr., J. Mattoso. 1970. Estrutura da língua portuguesa. Petrópolis: Vozes.

Cedergren, H. \& D. Sankoff. 1975. Nasals: A Sociolinguistic Study of Change in Progress. In Charles A. Ferguson, Larry M. Hyman \& John J. Ohala (eds.). NasálFest. Stanford.

Cho, T. \& Keating, P. 2009. Effects of initial position versus prominence in English. Journal of Phonetics 37.4: 466-485.

Collischonn, Gisela. 1994. Acento secundário em português. Letras de Hoje 29.4: 43-53.

Costa, Paula Pinheiro. 2019. A nasalização espontânea no português do brasil: uma análise multifatorial. MA thesis, Universidade Federal do Rio de Janeiro.

Cristófaro Silva, Thaïs, Maria Cantoni, Nívia Oliveira \& Izabel Miranda. 2017. Segmental loss and phonological representation. In Geoff Lindsey \& Andrew Nevins (eds.). Sonic Signatures. Amsterdam: John Benjamins, 216-230.

Crosswhite, Katherine. 1999. Vowel reduction in Optimality Theory. Doctoral dissertation, UCLA.

Damulakis, Gean. 2005. Fenômenos Variáveis sob uma Óptica Formal. MA thesis, Universidade Federal do Rio de Janeiro.

Faveri, Claudia Borges de. 1991. Analise da duração das vogais orais do portugues de Florianopolis-Santa Catarina. MA thesis, Universidade Federal de Santa Catarina.

Fougeron, C. (2001). Articulatory properties of initial segments in several prosodic constituents in French. Journal of Phonetics 29: 109-135.

França, Sebastião Adauto. 2009. O apagamento da vogal postônica não-final por falantes de Jaru, Estado de Rondônia. Maringá 31.2: 169-182.

Garcia, Guilherme D. 2017. Weight gradience and stress in Portuguese. Phonology 34.1: 41-79.

Gouskova, Maria. 2007. The reduplicative template in Tonkawa. Phonology 24: 367-396.

Hermans, Ben \& Leo Wetzels. 2012. Productive and Unproductive Stress Patterns in Brazilian Portuguese. Letras \& Letras 28.1: 77-114.

House, A. S. and K. N. Stevens. 1956. Analog Studies of the Nasalization of Vowels. Journal of Speech and Hearing Disorders 21: 218-232.

Hualde, J. I. \& Nadeu, M. 2011. Rhetorical stress in Spanish. In Word Stress: Theoretical and Typological Issues. Cambridge: Cambridge University Press, 228-252.

Jiménez, Jesus \& Maria-Rosa Lloret. 2013. Vocalic adjustments under Positional Markedness in Catalan and other Romance languages. In Camacho-Taboada, V., Jiménez-Fernández, Á. L., Martín-González, J. \& Reyes-Tejedor, M. (eds.). Information Structure and Agreement. Amsterdam/Philadelphia: John Benjamins, 319-336. 
Lipski, John M. 1992a. Metathesis as template matching: a Spanish example. Folia Linguistic Historica 11(1-2): 89-104.

Lipski, John M. 1992b. Spontaneous nasalization in the development of Afro-Hispanic language. Journal of Pidgin and Creole Languages 7.2: 261-305.

Marroquim, Mário. 2008. A língua do nordeste: Alagoas e Pernambuco. EDUFAL.

Martínez-Paricio, Violeta \& René Kager. 2015. The binary-to-ternary rhythmic continuum in stress typology: Layered feet and non-intervention constraints. Phonology 32.3: 459-504.

Moraes, Jõao. 1999. Um algoritmo para a correção/simulação da duração dos segmentos vocálicos em português. In Ester M. Scarpa (ed.). Estudos de Prosódia. Editoria UNICAMP, 69-84.

Moraes, Jõao. 2003. Secondary Stress in Brazilian Portuguese: perceptual and acoustical evidence. In Proceedings of the 15th ICPhS, Barcelona.

Moraes, João \& Wetzels, W. Leo. 1992. Sobre a duração dos segmentos vocálicos nasais e nasalizados em Português. Um exercício de Fonologia Experimental. Cadernos de Estudos Lingüísticos 23: 153-166.

Moreton, Elliott. 2002. Structural constraints in the perception of English stop-sonorant clusters. Cognition 84: 55-71.

Nevins, Andrew. 2012. Vowel Lenition and Fortition in Brazilian Portuguese. Letras de Hoje 47.3: 228-233.

Nevins, Andrew. 2015. Review of Natalie Operstein (2010). Consonant structure and prevocalization. Phonology 32: 307-317.

Ohala, John. 1975. Phonetic explanations for nasal sound patterns. In Charles A. Ferguson, Larry M. Hyman \& John J. Ohala (eds.). NasálFest. Stanford.

Ohala, John \& Maria Grazia Busà. 1995. Nasal loss before voiceless fricatives: a perceptually-based sound change. Rivista di Linguistica 7: 125-144.

Pons-Moll, Clàudia. 2008. Regarding the sonority of liquids. Some evidence from Romance. Paper presented at the 38th Linguistic Symposium on Romance Languages, University of Illinois at Urbana-Champaign.

Prince, Alan. 1990. Quantitative consequences of rhythmic organization. Chicago Linguistic Society 26(2): 355-398.

Ryan, Kevin M. 2014. Onsets contribute to syllable weight: Statistical evidence from stress and meter. Language 90: 309-341.

Sandalo, Filomena \& Hubert Truckenbrodt. 2003. Some notes on phonological phrasing in Brazilian Portuguese. Delta 19.1: 1-30.

Santana, Arthur. 2019. Neutralização das vogais átonas no português brasileiro. $\mathrm{PhD}$ thesis, Universidade de São Paulo.

Sayers, William. 2009. An Unnoticed Early Attestation of gringo 'Foreigner': Implications for Its Origin. Bulletin of Spanish Studies 86(3): 323-330.

Silva, Mário Coelho, Andrew Nevins \& James White. 2019. Domains and Prominence in Nasal Harmonization of Maxakalí Loanwords. To appear in International Journal of American Linguistics.

Smith, Jennifer L. 2005. Phonological augmentation in prominent positions. Routledge.

Souza e Melo, Sandra Maria Mendes. 2015. Processos fonológicos presentes na escrita: um estudo de caso com alunos do $9^{\circ}$ ano de uma escola da rede estadual de Recife. Universidade Federal de Pernambuco. 
Wetzels, W. L. M. 1997. The lexical representation of nasality in Brazilian Portuguese. Probus 9.2: 203-232.

Wetzels, W. L. (2007). Primary word stress in Brazilian Portuguese and the weight parameter. Journal of Portuguese Linguistics 5: 9-58.

Zoll, Cheryl. 1998. Positional Asymmetries and Licensing. ROA-282.

Zuraw, Kie. 2002. Aggressive reduplication. Phonology 19: 395-439.

\section{Appendix: List of Non-Standard forms with Spontaneous Nasalization}

\begin{tabular}{|c|c|c|c|c|}
\hline Num & Standard Form & Nasalized form (written) & Phonetic Transcription & \\
\hline 1 & acolchoado & aconchoado & [a., kõ.ju.'a.du] & padded \\
\hline 2 & afligir & aflingir & [,a.flĩ.' 'zih] & to ail \\
\hline 3 & aipim & aimpim & [,a.ĩ.'pĩ] & yucca \\
\hline 4 & abacaxi & ambacaxi & {$\left[\tilde{a} \cdot\right.$, ba.ka.' $\left.\int_{\mathrm{I}}\right]$} & pineapple \\
\hline 5 & abundância & ambundância & [ã.bũ.'dã.sje] & abundance \\
\hline 6 & aviamento & avinhamento & [a., vĩ.na.'mẽ.tu] & goodwill \\
\hline 7 & bandido & bandindo & 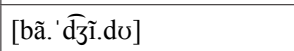 & bandit \\
\hline 8 & bagunça & bangunça & [bã.'gũ.se] & mess \\
\hline 9 & banqueta & banquenta & [bã. 'kẽ.te] & footstool \\
\hline 10 & banquete & banquente & [bã.'kẽ.ţ $\mathrm{I}]$ & banquet \\
\hline 11 & biblioteca & binblioteca & [bĩ., bli.o.' te.ke] & library \\
\hline 12 & cidadão & cindadão & [, sĩ.da.' dã w] & citizen \\
\hline 13 & ciúme & cinhume & [sĩ.'ju.mi] & jealousy \\
\hline 14 & cobaia & combaia & [kõ.'baj.je] & guinea pig \\
\hline 15 & comigo & comingo & [ku.'mĩ.go] & with-me \\
\hline 16 & colônia & conlônia & [kõ.' 'lõ.nje] & colony \\
\hline 17 & corromper & conrromper & [. kõ.hõ.'peh] & to corrupt \\
\hline 18 & conselho & consenlho & [kõ.'sẽ. $\kappa \mho]$ & advice \\
\hline 19 & convencido & convencindo & [,kõ.vẽ.'si.du] & convinced \\
\hline 20 & cozinha & conzinha & [kõ.'zĩ.na] & kitchen \\
\hline 21 & detrimento & dentrimento & [.dẽ.tri.'mẽ.to] & detriment \\
\hline 22 & desviar & desvinhar & 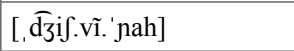 & to divert \\
\hline 23 & distinguir & dinstinguir & [. $\widehat{\mathrm{d} 3} \tilde{1} \int . \widehat{\mathrm{t}}\left[\tilde{1} .{ }^{\prime}\right.$ 'gwih] & to distinguish \\
\hline 24 & distintivo & distintivo & 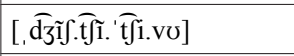 & distinctive \\
\hline 25 & empoderado & emponderado & [.1̃.põ.de.'ra.de] & empowered \\
\hline 26 & empoderamento & emponderamento & [,1.põ.,de.ra.'mẽ.to] & empowerment \\
\hline 27 & eclipse & enclipse & [ĩ. 'kli.pı.sI] / [ẽ.' 'kli.pı.sI] & eclipse \\
\hline 28 & educação & enducação & [ĩ. du.ka. 'sãw] & education \\
\hline
\end{tabular}




\begin{tabular}{|c|c|c|c|c|}
\hline Num & Standard Form & Nasalized form (written) & Phonetic Transcription & \\
\hline 29 & educador & enducador & [ĩ., du.ka.'doh] & educator \\
\hline 30 & engajado & enganjado & [.ĩ.gã.'za.do] & engaged \\
\hline 31 & eleger & enleger & [.ĩ.le.'zeh] & to elect \\
\hline 32 & elucidar & enlucidar & [ĩ.,lu.si.'dah] & to elucidate \\
\hline 33 & essencial & enssencial & [ĩ.,sẽ.si.' aw] / [ẽ., sẽ.si. 'aw] & essential \\
\hline 34 & etiqueta & entiqueta & 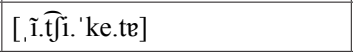 & label \\
\hline 35 & entupido & entunpido & [.î.tũ.'pi.dv] & stuffed up \\
\hline 36 & feiura & feinhura & [fẽ̃̃.' 'nu.re] & ugliness \\
\hline 37 & fruta & frunta & ['frũ.te] & fruit \\
\hline 38 & governo & governo & [gõ. 'vefi.no] & government \\
\hline 39 & hesitei & hensitei & [.ĩ.zi.'tej] & hesitated-1sg \\
\hline 40 & hesitou & hensitou & [.ĩ.zi. 'tow] & hesitated-3sg \\
\hline 41 & hibernar & himbernar & [.ĩ.bef.' nah] & to hibernate \\
\hline 42 & hidratado & hindratado & [.ĩ.dra.'ta.dv] & hydrated \\
\hline 43 & hidratar & hindratar & [., ĩ.dra.'tah] & to hydrate \\
\hline 44 & higiênico & hingienico & [.ĩ.zi.'ẽ.nr.kv] & hygienic \\
\hline 45 & hiato & hinhato & [ĩ. 'na.to] & hiatus \\
\hline 46 & hipnotizado & hinpnotizando & [,ĩ.pi.,no.ţ]1.'zã .dv] & hypnotized \\
\hline 47 & hipnotizar & hinpnotizar & [.ĩ.pi.,no. $\widehat{\operatorname{tg}}$ ji.'zah] & to hypnotize \\
\hline 48 & hipócrita & hinpócrita & [ĩ.'po.krı.te] & hypocrite \\
\hline 49 & hipoteca & hinpoteca & [.,̃.po.'te.ke] & mortgage \\
\hline 50 & história & hinstória & [î̃.'to.rje] & history \\
\hline 51 & histórico & hinstórico & [ĩ̃. 'to.rr.kv] & record \\
\hline 52 & horrível & honrrível & [õ.'hi.vew] / [ũ.'hi.vew] & horrible \\
\hline 53 & humilhação & huminlhação & [u.,mĩ.Ka.'sãw] & humiliation \\
\hline 54 & ideal & indeal & [.ĩ.de.'aw] & ideal \\
\hline 55 & ibérico & imbérico & [ĩ.'be.rı.kv] & Iberian \\
\hline 56 & impressão & imprensão & [.ĩ.prẽ.' sã̃̃] & impression \\
\hline 57 & impressionado & imprenssionado & [ĩ.,prẽ.sjo.’na.du] & impressed \\
\hline 58 & impressionar & imprenssionar & [ĩ.,prẽ.sjo.'nah] & to impress \\
\hline 59 & ibope & inbope & [ĩ.'bo.pr] & $\begin{array}{l}\text { Brazilian Institute } \\
\text { of Public Opinion } \\
\text { and Statistics }\end{array}$ \\
\hline 60 & ebulição & inbulição & [ĩ. bu.li. 'sãw] / [ẽ. bu.li. 'sãw] & boiling \\
\hline 61 & içamento & inçamento & [.ĩ.sa.'mẽ.to] & hoisting \\
\hline 62 & içar & inçar & [ĩ.'sah] & to hoist \\
\hline 63 & ícone & íncone & ['î.kõ.nI] & icon \\
\hline
\end{tabular}




\begin{tabular}{|c|c|c|c|c|}
\hline Num & Standard Form & Nasalized form (written) & Phonetic Transcription & \\
\hline 64 & iconografia & inconografia & [,ĩ.ko., no.gra.' fi.e] & iconography \\
\hline 65 & economia & inconomia & [ĩ. ko.no.'mi.e] & economy \\
\hline 66 & econômico & inconomico & [.ĩ.ko.'no.mı.kv] & economic \\
\hline 67 & icterícia & incterícia & [.̃..ki.te.' 'ri.sje] & jaundice \\
\hline 68 & idade & indade & [ĩ.' da.d̄̄I] & age \\
\hline 69 & idealismo & indealismo & [ĩ.,de.a.'lif.mv] & idealism \\
\hline 70 & ideia & indeia & [ĩ.' dej.je] & idea \\
\hline 71 & idêntico & indêntico & [ĩ.' dẽ.ţโt.kv] & identical \\
\hline 72 & identidade & indentidade & 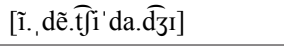 & identity \\
\hline 73 & indigente & indingente & 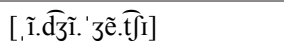 & indigente \\
\hline 74 & indignação & indinguinação & 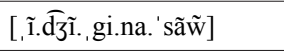 & indignation \\
\hline 75 & indignado & indinguinado & [ĩ., đَ̧̃̃.gi.'na.dv] & indignant \\
\hline 76 & idioma & indioma & [.̃. İ.dzi. 'õ.me] & language \\
\hline 77 & idiossincrasia & indiossincrasia & [,ĩ.djo., sĩ.kra.'zi.e] & idiosyncrasy \\
\hline 78 & idiota & indiota & [.,. I.dु̄i.'o.te] & idiot \\
\hline 79 & idiotismo & indiotismo & 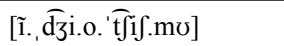 & idiocy \\
\hline 80 & editar & inditar & 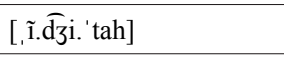 & to edit \\
\hline 81 & idolatra & indolatra & [.ĩ.do'la.tre] & idolize-3sg \\
\hline 82 & idólatra & indólatra & [ĩ.' do.le.tre] & idolatrous \\
\hline 83 & idolatrar & indolatrar & [ĩ.,do.la.'trah] & to idolize \\
\hline 84 & idolatria & indolatria & [ĩ., do.la. 'tri.e] & idolatry \\
\hline 85 & idôneo & indoneo & [ĩ. 'dõ.njo] & legitimate \\
\hline 86 & idoso & indoso & [ĩ.'do.zv] & elderly \\
\hline 87 & efetuar & infetuar & [ĩ., fe.tu.'ah] & to conduct \\
\hline 88 & ignição & ingnição & [ĩ., gi.ni. 'sãw] & ignition \\
\hline 89 & ignóbil & ingnobil & [.ĩ.gi.'no.brw] & ignoble \\
\hline 90 & ignorado & ingnorado & [ĩ. gi.no.' 'ra.dv] & ignored \\
\hline 91 & ignorância & ingnorancia & [ĩ. gi.no.' rã.sje] & ignorance \\
\hline 92 & ignorante & ingnorante & [ĩ. gi.no. 'rã. $\widetilde{t}[\mathrm{I}]$ & ignorant \\
\hline 93 & ignorar & ingnorar & [ĩ. gi.no.' 'rah] & to ignore \\
\hline 94 & egoísta & ingoísta & [.ĩ.go.'if.te] & selfish \\
\hline 95 & igreja & ingreja & [ĩ.'gre.3p] & church \\
\hline 96 & igual & ingual & [ĩ.' gwaw] & equal \\
\hline 97 & igualar & ingualar & [.̃̃.gwa.' lah] & to equalize \\
\hline 98 & igualdade & ingualdade & 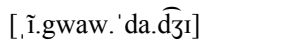 & equality \\
\hline 99 & iguaria & inguaria & [.ĩ.gwa.' ri.e] & delicacy \\
\hline
\end{tabular}




\begin{tabular}{|c|c|c|c|c|}
\hline Num & Standard Form & Nasalized form (written) & Phonetic Transcription & \\
\hline 100 & iate & inhate & 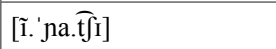 & yacht \\
\hline 101 & ilegal & inlegal & [, 1.le.'gaw] & illegal \\
\hline 102 & ilegítimo & inlegítimo & 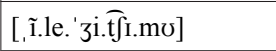 & illegitimate \\
\hline 103 & ilegível & inlegivel & [.1.le.' 'zi.vew] & illegibile \\
\hline 104 & ileso & inleso & [i.'le.zu] & unscathed \\
\hline 105 & ilícito & inlicito & [ĩ. 'li.si.to] & illicit \\
\hline 106 & ilimitado & inlimitado & [ĩ. li.mi.'ta.dv] & unlimited \\
\hline 107 & ilógico & inlógico & [ĩ.'lo.gI.kJ] & illogical \\
\hline 108 & iludir & inludir & [.1.lu.'dih] & to delude \\
\hline 109 & Iluminismo & inluminismo & {$[$ ĩ. lu.mi.'nif.mv] } & Enlightenment \\
\hline 110 & ilusão & inlusão & [.,̃.lu.'zãw] & illusion \\
\hline 111 & ilustrar & inlustrar & [.1̃.luf.'trah] & to illustrate \\
\hline 112 & ilustre & inlustre & [ĩ.'luf.trI] & illustrious \\
\hline 113 & equivalente & inquivalente & {$[\tilde{1} .$, ki.va.' '1ẽ.t $\widehat{\mathrm{t}} \mathrm{I}]$} & equivalent \\
\hline 114 & equívoco & inquivoco & [i. 'ki.vo.ku] & misconception \\
\hline 115 & irracional & inracional & {$[1$ i. ha.sjo.' naw $]$} & irrational \\
\hline 116 & irradiação & inradiação & 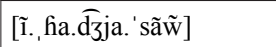 & radiation \\
\hline 117 & irado & inrado & [ĩ.'ra.dv] & irate \\
\hline 118 & irrealizável & inrealizável & [.ĩ.fe., a.li.' za.vew] & unattainable \\
\hline 119 & irreconciliável & inreconciliável & [ĩ., he.kõ., si.li.' a.vew] & unreconcilable \\
\hline 120 & irreconhecível & inreconhecível & [.ĩ.he., kõ.ne.'si.vew] & unrecognizable \\
\hline 121 & irrecuperável & inrecuperável & [, 1.he., ku.pe.' ra.vew] & unrecoverable \\
\hline 122 & irrecusável & inrecusável & {$[$ ĩ., he.ku.'za.vew] } & undeniable \\
\hline 123 & ironia & inronia & [,1.ro.'ni.e] & irony \\
\hline 124 & ironizar & inronizar & [ĩ.' 'ro.ni.'zah] & to mock \\
\hline 125 & irreal & inrreal & [.1. he.'aw] & unreal \\
\hline 126 & irredutível & inrredutível & 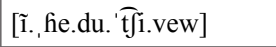 & relentless \\
\hline 127 & irrefletido & inrrefletido & {$\left[\right.$ i. , he.fle. ' $\left.\mathrm{t} \int \mathrm{i} . \mathrm{dv}\right]$} & thoughtless \\
\hline 128 & irrefutável & inrrefutável & [ĩ., he.fu. 'ta.vew] & irrefutable \\
\hline 129 & irregularidade & inrregularidade & 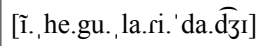 & irregularity \\
\hline 130 & irrelevante & inrrelevante & {$[$ i. , he.le. 'vã . $\widetilde{\mathrm{t}} \mathrm{I}]$} & irrelevant \\
\hline 131 & irreligioso & inrreligioso & [,i.fe., li.zi.'o.zu] & unreligious \\
\hline 132 & irremediável & inrremediável & [, 1.he. me. $\widehat{d}$ żi.'a.vew] & irretrievable \\
\hline 133 & irremovível & inrremovível & [ĩ., he.mo.'vi.vew] & unremovable \\
\hline 134 & irreparável & inrreparável & [ĩ., he.pa.' ra.vew] & unrepairable \\
\hline 135 & irresponsável & inrreponsável & 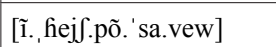 & irresponsible \\
\hline
\end{tabular}




\begin{tabular}{|c|c|c|c|c|}
\hline Num & Standard Form & Nasalized form (written) & Phonetic Transcription & \\
\hline 136 & irrepreensível & inrrepreensível & [,ĩ.fie.,pre.ẽ. 'si.vew] & irreproachable \\
\hline 137 & irresistível & inrresistível & [ĩ., he.zif.' 't fi.vew] & irresistible \\
\hline 138 & irrestrito & inrrestrito & [.ĩ.hejS.'tri.to] & unrestricted \\
\hline 139 & irreverente & inrreverente & [ĩ., he.ve. 'rẽ.ț $[\mathrm{I}]$ & irreverent \\
\hline 140 & irrigar & inrrigar & [.̃..fii.'gah] & to irrigate \\
\hline 141 & irritação & inrritação & [ĩ., hi.ta. 'sãw] & irritation \\
\hline 142 & irritar & inrritar & [.̃̃.fi.'teh] & to irritate \\
\hline 143 & isenção & insenção & [.,̃.zẽ. 'sã̃̃] & exemption \\
\hline 144 & isento & insento & [ĩ.'zẽ.to] & exempt \\
\hline 145 & esgrima & insgrima & [ĩ̂.' gri.me] & fencing \\
\hline 146 & isolado & insolado & [.ĩ.zo.'la.do] & isolated \\
\hline 147 & isolar & insolar & [.ĩ.zo.'lah] & to isolate \\
\hline 148 & isopor & insopor & [., 1.zo.'poh] & styrofoam \\
\hline 149 & específico & inspecífico & [.ĩf.pe. 'si.fr.kv] & specific \\
\hline 150 & expectativa & inspectativa & [.ĩf.pe, ki.ta.'ti.ve] & expectation \\
\hline 151 & especulou & inspeculou & [ĩf.,pe.ku.' low] & speculated-3sg \\
\hline 152 & esplêndido & insplendido & 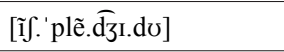 & splendid \\
\hline 153 & esplendor & insplendor & [.î̃.plẽ.' doh] & splendor \\
\hline 154 & espontâneo & inspontâneo & 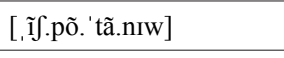 & spontaneous \\
\hline 155 & isqueiro & insqueiro & [ĩs.'ke.ro] & lighter \\
\hline 156 & esquema & insquema & [ĩ. ' ke.me] & scheme \\
\hline 157 & estagnado & instagnado & [ĩ̃., ta.gi.'na.dv] & stagnant \\
\hline 158 & histérica & instérica & [ĩf. 'te.rI.ke] & hysterical \\
\hline 159 & estima & instima & [î̀. 't & esteem \\
\hline 160 & estimulo & \begin{tabular}{|l|} 
instimulo \\
\end{tabular} & 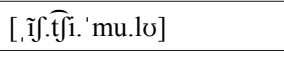 & stimulate-1sg \\
\hline 161 & estímulo & instímulo & [ĩ̂.' 'tfi.mu.lv] & stimulus \\
\hline 162 & extraordinário & instraordinário & [.î̃.tra., oh.d̄̄i.'na.rrw] & extraordinary \\
\hline 163 & estúpido & instúpido & [î̃. 'tu.pi.do] & stupid \\
\hline 164 & ítem & intem & ['ĩ.tẽj] & item \\
\hline 165 & interromper & intenrromper & [ĩ., tẽ.hõ.'peh] & to interrupt \\
\hline 166 & itinerante & intinerante & 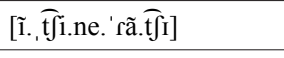 & itinerant \\
\hline 167 & itinerário & intinerário & [ĩ., & itinerary \\
\hline 168 & exame & inzame & [ĩ.'za.mI] & exam \\
\hline 169 & eximir & inzimir & [.1̃.zi.'mih] & to shirk \\
\hline 170 & irregular & inrregular & [ĩ., he.gu.' 'lah] & irregularity \\
\hline 171 & jejum & jenjum & [зе̃'зи̃] & fasting \\
\hline
\end{tabular}




\begin{tabular}{|c|c|c|c|c|}
\hline Num & Standard Form & Nasalized form (written) & Phonetic Transcription & \\
\hline 172 & joelho & jonhelho & [jũ.'ne.Ku] & knee \\
\hline 173 & liberdade & linberdade & 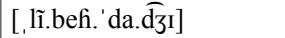 & liberty \\
\hline 174 & livro & linvro & ['lĩ.vro] & book \\
\hline 175 & mandioca & mandinhoca & 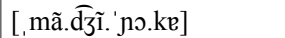 & manioc \\
\hline 176 & maracujá & maracunjá & [ma., ra.kũ.'za] & passionfruit \\
\hline 177 & mendigo & mendingo & 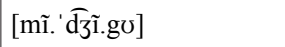 & mendicant \\
\hline 178 & melancolia & menlancolia & [mẽ., lã.ko.'li.e] & melancholy \\
\hline 179 & misturar & minsturar & [mĩj.'tu.rah] & to $\operatorname{mix}$ \\
\hline 180 & mortadela & mortandela & [,moh.tã.'de.le] & mortadela \\
\hline 181 & necessidade & nencessidade & [nẽ., se.si. 'da.dzI $]$ & necessity \\
\hline 182 & nicho & nincho & ['nĩ.fo] & niche \\
\hline 183 & nítido & níntido & ['nĩ. $\widetilde{t}$ I.dv] & clear \\
\hline 184 & obrigado & obringado & [,o.brĩ. 'ga.dv] & thank you \\
\hline 185 & ocorreu & oncorreu & [.õ.ko.' hew] & occurred-3sg \\
\hline 186 & pentecostal & pentencostal & [pẽ. tẽ.kof.' taw] & pentecostal \\
\hline 187 & pentecostes & pentencostes & [.pẽ.tẽ.'kof.tfIJ] & Pentecost \\
\hline 188 & picadeiro & pincadeiro & [.pĩ.ka.'de.rv] & arena \\
\hline 189 & pichação & pinchação & [.pĩ.fa.'sãw] & grafitti \\
\hline 190 & picolé & pincolé & [.pĩ.ko.'le] & popsicle \\
\hline 191 & piolho & pinholho & [pĩ.' jo. $\Lambda \mho]$ & louse \\
\hline 192 & possibilidade & possinbilidade & [,po.sĩ., bi.li.' da. $\widehat{d}$ zI $]$ & possibility \\
\hline 193 & pudim & pundim & 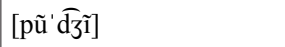 & pudding \\
\hline 194 & reiterar & reinterar & [he., ĩ.te.' 'rah] & to reiterate \\
\hline 195 & reivindicar & reinvindicar & [hẽj., vĩ.ḑzi. 'kah] & to claim \\
\hline 196 & restrição & restrinção (ões) & 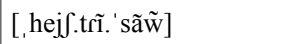 & restriction \\
\hline 197 & sanduíche & sanduinche & [. sã.du.'ĩ. $\mathrm{i}$ I] & sandwich \\
\hline 198 & seguro & segunro & [si. 'gũ.fo] & secure \\
\hline 199 & sibilante & simbilante & [. sĩ.bi.' lã.t $\widehat{\text { f }}[$ ] & sibilante \\
\hline 200 & sigilo & singilo & [sĩ.'zi.lv] & confidentiality \\
\hline 201 & sigiloso & singiloso & [.sĩ.zi.'lo.zv] & confidential \\
\hline 202 & sobrancelha & sombracelha & [, sõ.bra.'se. $K \mathrm{e}]$ & eyebrow \\
\hline 203 & sobrancelha & sombrancelha & [, sõ.brã.'se. $K \mathrm{e}]$ & eyebrow \\
\hline 204 & sujeito & sunjeito & [sũ.'zej.to] & subject \\
\hline 205 & tranquilo & tranquinlo & [trã.' qwĩ.lu] & tranquil \\
\hline 206 & trufado & trunfado & [trũ.'fa.dv] & truffled \\
\hline 207 & uruguai & unruguai & [.ũ.ru.'gwaj] & Uruguay \\
\hline
\end{tabular}




\begin{tabular}{|c|c|c|c|c|}
\hline Num & Standard Form & Nasalized form (written) & Phonetic Transcription & \\
\hline 208 & usufruir & unsufruir & [ũ., zu.fru.'ih] & to make use of \\
\hline 209 & útero & untero & ['ũ.te.f于] & uterus \\
\hline 210 & utilizado & untilizado(a) & [ũ.,$\left.\widehat{t} \int 1 . l i . ' z a . d v\right]$ & used \\
\hline 211 & utilizar & untilizar & [ũ., ţfi.li.'zah] & to use \\
\hline 212 & utopia & untopia & [,ũ.to.'pi.e] & utopia \\
\hline 213 & veicular & veincular & [ve., i..ku.' lah] & to convey \\
\hline 214 & ventilador & ventinlador & [vẽ. 't]î.la.' do] & fan \\
\hline 215 & Vicente & vincente & [vĩ.' sẽ.ţ] & proper name \\
\hline 216 & vídeo & vindeo & ['vĩ.ब̄ंjo] & video \\
\hline 217 & vigência & vingência & [vĩ.'zẽ.sje] & validity \\
\hline 218 & viado & vinhado & [vĩ.'na.dv] & deer \\
\hline 219 & viagem & vinhagem & [vĩ.'na.jẽj̃] & voyage \\
\hline
\end{tabular}

